\title{
SURVIVAL PROBABILITY COMPARISON OF DKI JAKARTA RESIDENTS BASED ON GENDER AND MARITAL STATUS
}

\author{
Tri Wahyudi ${ }^{1}$, Samsul Anwar ${ }^{2}$, Ridha Ferdhiana ${ }^{2}$ \\ ${ }^{1}$ Central Bureau of Statistics for Aceh Tenggara District, Aceh, Indonesia \\ ${ }^{2}$ Statistics Department, Faculty of Mathematics and Natural Sciences, Universitas Syiah Kuala, Aceh, Indonesia \\ Corresponding Author: Samsul Anwar \\ E-mail: samsul.anwar@unsyiah.ac.id
}

\begin{abstract}
Human life quality in an area can be determined through the Human Development Index (HDI). One of the fundamental components for the HDI composition is the Life Expectancy Rate (LER). Even though DKI Jakarta Province has a high HDI, research on the factors that influence LER is still fascinating to do. This study aims to compare the survival probability of the DKI Jakarta residents based on gender (male and female) and marital status (unmarried and married) variables. This study analyzed the lifespan data of 464 people who were calculated from birth to death in 2017. The data were analyzed using a lifetime analysis method with a parametric approach which refers to selecting the probability distributions that best fits the research data. The results showed there was no difference in survival probability between the male and female populations. Meanwhile, married residents have a greater survival probability than those who were unmarried. Thus, the Provincial Government of DKI Jakarta needs to increase the percentage of the married population to increase LER, leading to an increase in regional HDI, for example, through economic empowerment programs and optimization of the Planning Generation (GenRe) program.
\end{abstract}

Keywords: lifespan, lifetime analysis, DKI Jakarta resident, gender, marital status, survival probability

\begin{abstract}
ABSTRAK
Kualitas hidup manusia di suatu daerah dapat ditentukan melalui Indeks Pembangunan Manusia(IPM). Salah satu komponen penting penyusun IPM adalah Angka Harapan Hidup (AHH). Meskipun Provinsi DKI Jakarta memiliki IPM yang tinggi namun penelitian tentang faktor yang mempengaruhi AHH tetap menarik untuk dilakukan. Penelitian ini bertujuan untuk membandingkan peluang tetap hidup (survival) penduduk DKI Jakarta berdasarkan variabel jenis kelamin (laki-laki dan perempuan) serta status perkawinan (belum dan sudah menikah). Penelitian ini menganalisis data usia hidup 464 penduduk yang dihitung sejak lahir sampai dengan meninggal dunia pada tahun 2017. Data tersebut dianalisis dengan metode analisis masa hidup (lifetime analysis) dengan pendekatan parametrik yang mengacu pada pemilihan distribusi peluang yang paling sesuai dengan data penelitian. Hasil penelitian menunjukkan bahwa tidak adanya perbedaan peluang survival antara penduduk lakilaki dan perempuan. Sementara itu, penduduk yang berstatus sudah menikah memiliki peluang survival yang lebih besar dibandingkan dengan penduduk yang berstatus belum menikah. Dengan demikian, Pemerintah Provinsi DKI Jakarta perlu meningkatkan persentase penduduk yang berstatus sudah menikah dalam upaya peningkatan AHH yang berujung pada peningkatan IPM daerah misalnya melalui program pemberdayaan ekonomi dan pengoptimalan program Generasi Berencana (GenRe).
\end{abstract}

Kata kunci: usia hidup, analisis masa hidup, penduduk DKI Jakarta, jenis kelamin, status perkawinan, peluang survival

\section{INTRODUCTION}

The average lifespan of the population in an area is measured through the Life Expectancy Rate (LER). LER is an indicator that can determine the population's health status in a region or country. In Indonesia, LER is an important indicator in preparing the Human Development Index, known as HDI
(Danasari and Wibowo, 2017). According to Dwiningtias and Mahampang (2019), HDI is an index that can determine the population's level of life quality in an area. HDI has a significant influence on various population problems like poverty (Hanifa and Wibowo, 2017). DKI Jakarta, which is also the capital city the Republic of Indonesia, has a high population 
diversity level, reflecting the general social, economic, and demographic conditions of the Indonesian population. Based on BPS DKI Jakarta Province (2020) data, the total population of DKI Jakarta in 2019 was $10,557,810$ people with details of $5,285,321$ of whom were males, and 5,272,489 others were females. A total of 5,128,264 people had single status, and 5,312,151 others were married, while the rest were divorced life/death. DKI Jakarta Province is a province with the highest HDI in Indonesia, amounting to 80.76 . The LER of DKI Jakarta's population in 2019 was also relatively high, namely 70.96 years for male residents and 74.68 years for female residents.

In general, increasing LER in an area will increase the HDI of that area (Sari, Harianto, and Falatehan, 2016). So that research on LER becomes interesting to encourage an increase in the HDI of an area. Several factors influence LER in general. According to Beckman (2016), there were 9 factors influencing LER, namely gender, genetics, pregnancy and childhood, marital status, social and economic status, education, ethnicity, lifestyle, and advances in health technology. Another study from Chan and Kamala Devi (2015) about the factors that influence LER in three Asean member countries, namely Singapore, Malaysia, and Thailand, concluded that LER in these three countries was affected by demographics, socioeconomic factors, and sources of health concerns.

Both studies indicate demographic factors are one of the essential factors that can influence LER. Gender and marital status are two crucial variables often used in describing the demographic conditions of the population of an area. Research on LER associated with these two demographic variables is rarely conducted in Indonesia, especially those using micro (individual) data. Accordingly, this research was conducted to find out differences in survival probability of the residents of DKI Jakarta based on gender and marital status variables using a lifetime analysis.

Lifetime analysis is a statistical method that can be used to analyze a time duration of an event (Jiang, 2015). The data used in lifetime analysis are survival data, which includes the observed subject's time and survival status. The primary condition is there must be a starting time and an ending time of an event. In this case, the human lifespan is calculated from birth to death.
Observation behavior in lifetime analysis can be seen through the value of Cumulative Distribution Function (CDF), Probability Density Function (PDF), Hazard, and Survival. Among these four functions, the survival function is essential in the lifetime analysis.

The survival function describes an individual's probability or subject experiencing an event after a certain point of time (Jiang, 2015). One way to estimate the values of the survival function is to use a parametric approach. The process of calculating the survival probability value through a parametric approach uses a probability distribution that is appropriate or closest to the distribution of the actual observed data. In lifetime analysis, several probability distributions can be used. These probability distributions need to be tested one by one with the empirical data to obtain a probability distribution that best fits the distribution of the research data analyzed. This study uses four probability distributions frequently used in lifetime analysis, namely the Exponential, Gamma, Weibull, and Gumbel distributions. Those four probability distributions generally describe various natural phenomena, including human lifespan. This study aims to compare the survival probability of DKI Jakarta residents based on gender and marital status variables. Information about the survival probability will assist the Provincial Government of DKI Jakarta in increasing LER which encourages an increase in HDI in the country's capital city.

\section{METHODS}

The approach used in this study was a quantitative approach based on cross-sectional data. The data employed in this study were the lifespan data of residents of DKI Jakarta Province who died in 2017. The data were obtained from the Forestry Service, the funeral service division of DKI Jakarta Province, through the website. The number of samples used in this study was 464 people who were randomly selected through three stages: selecting the funeral month, selecting the funeral date in the selected month, and finally selecting the sample of individuals buried on the selected date. Each selected sample was recorded on birth and death and other demographic information, including gender and marital status. 
There are three variables used, namely lifespan, gender, and marital status. Those three variables are fully recorded at the DKI Jakarta Provincial Forestry Service. The first variable in the form of age is the duration of a resident's time interval calculated from birth to death, measured in units of years. The second variable is gender divided into male and female. Furthermore, the variable marital status is also divided into two, unmarried and married.

The statistical method used to calculate the survival probability from the sample data is a lifetime analysis. The survival probability for each variable is estimated through a parametric approach by selecting the probability distribution that best fits the research data pattern. The software used in analyzing the research data is $\mathrm{R}$ version 3.3.1 and Microsoft Excel 2013

The stages of data analysis in this study were divided into eight steps. First, sampling selection, namely, sort out DKI Jakarta residents who died in 2017 through the DKI Jakarta Provincial Forestry Service website. Second, cleaning process, data input and calculating the sample's lifespan. Third, grouping samples based on variables of gender and marital status. Fourth, conducting descriptive statistical analysis by displaying summary statistics from the research data. Fifth, choosing the most suitable probability distributions (Exponential $\{\exp (\lambda)\}$, Gamma \{gamma $(k, \lambda)\}$, Weibull \{weibull $(\alpha, \lambda))\}$ or Gumbel \{gumbel $(\mu, \beta)\})$ with research data based on the smallest Akaike Information Criterion (AIC) value criterion. Those four probability distributions need to be tested one by one and compared to each other to determine which probability distribution best fits the research data. Sixth, estimating parameters of the probability distribution using the MLE or Maximum Likelihood Estimation method. MLE is a parameter estimation method that can produce relatively accurate parameter values, especially for models with large sample sizes. Seventh, calculating and interpreting the survival probability value based on gender and marital status variables through survival charts. In calculating the survival probability, it is necessary to calculate the Probability Density Function (PDF) and the Cumulative Distribution Function (CDF). The survival probability value is calculated by the $1-C D F$ equation. Eighth, testing the difference in the value of survival probability based on gender and marital status variables using the log-rank test. Log-rank test is a statistical method used to determine whether there is a difference in survival probability based on gender and marital status variables.

\section{RESULT}

\section{Overview of Research Data}

The general description of the research variables and data used is seen through descriptive analysis. Descriptive analysis in this study is displayed in the form of a summary statistics table in Table 1. The descriptive statistics presented in Table 1 show that the number of male samples is more than the female with a percentage of $58.19 \%$ versus $41.81 \%$. Meanwhile, the number of samples with married status is almost six times more than the number of samples that are unmarried. The number of samples analyzed with unmarried status decreased from 67 to 42 people because 25 people were under 19 years of age for the male sample and under 16 for the female sample. Reducing the number of samples is carried out so that the comparison of lifespans based on marital status is unbiased because they have the same baseline age. Thus, the number of samples used to calculate the survival probability based on marital status was 439 .

Furthermore, Table 1 also shows the average lifespan of DKI Jakarta residents who died in 2017 for the female population was 57.93 years, slightly higher than the male population, namely 56.59 years. Furthermore, when the data were grouped based on marital status, the average lifespan for married people was 62.47 years, much higher than unmarried, which was 39.11 years.

\section{Lifetime Analysis}

\section{Selection of the Probability Distribution Based on the Smallest AIC Value Criterion}

The calculation of the survival probability through a parametric approach in this study uses an appropriate probability distribution, which is the closest to the distribution of the observed data (lifespan). There are four probability distributions tested in this study: Exponential, Gamma, Weibull, and Gumbel distributions. The criteria used in selecting the most suitable probability 
Table 1. Descriptive statistics of lifespan data (years) based on gender and marital status variables

\begin{tabular}{lcccc}
\hline Variable & $\mathbf{N}(\%)$ & Mean \pm SD & Minimum & Maximum \\
\hline Gender & & & & \\
\hline Male & $270(58.19)$ & $56.59 \pm 20.37$ & 0.0014 & 96.64 \\
Female & $194(41.81)$ & $57.93 \pm 19.22$ & 0.0014 & 90.83 \\
\hline Marital status & & & & \\
\hline Unmarried & $67(14.44)$ & $39.11 \pm 15.67$ & 16.16 & 90.83 \\
Married & $397(85.56)$ & $62.47 \pm 13.67$ & 23.67 & 96.64 \\
\hline
\end{tabular}

Table 2. AIC values of the probability distributions of the lifespan data (years) based on gender and marital status variables

\begin{tabular}{lllll}
\hline \multirow{2}{*}{$\begin{array}{l}\text { Probability } \\
\text { Distribution }\end{array}$} & Male & Female & Unmarried & Married \\
\cline { 2 - 5 } & $2,721.38$ & $1,964.99$ & 393.98 & $4,078.99$ \\
Exponential & $2,696.87$ & $1,904.01$ & $345.18 *$ & $3,241.38$ \\
Gamma & $2,609.01$ & $1,812.90$ & 350.69 & $3,195.81 *$ \\
Weibull & $2,343.46 *$ & $1,664.38 *$ & 372.73 & $3,217.84$ \\
Gumbel & &
\end{tabular}

distribution are using the smallest AIC value criteria. The AIC values for the four tested probability distributions are shown in Table 2 .

Based on Table 2, it is known that the probability distribution that has the smallest AIC value for both sexes (male and female) is the same probability distribution, namely the Gumbel distribution with AIC values of 2,343.46 and 1,664.38, respectively. This result indicates that the lifespan of the sample of DKI Jakarta residents, both male and female who died in 2017, followed Gumbel distribution. Meanwhile, for the unmarried marital status variable, the probability distribution with the smallest AIC value is the Gamma distribution with an AIC value of 345.18. The probability distribution with the smallest AIC value for married marital status variables is the Weibull distribution with an AIC value of 3,195.81. Based on the criteria for the smallest AIC value, the lifespan of a sample of DKI Jakarta residents with unmarried marital status who died in 2017 follows the Gamma distribution, while the lifespan of residents with married marital status follows the Weibull distribution.

\section{Estimation of Probability Distribution Parameter}

The parameter values of each suitable probability distribution for gender and marital status variables were estimated using MLE or Maximum Likelihood Estimation method. The parameter values for each of these probability distributions are shown in Table 3.

Table 3. Estimation of probability distribution parameters using Maximum Likelihood Estimation (MLE)

\begin{tabular}{|c|c|c|c|c|}
\hline Variable & Category & $\begin{array}{l}\text { Probability } \\
\text { Distribution }\end{array}$ & Parameter & Value \\
\hline \multirow{3}{*}{ Gender } & Male & Gumbel & $\begin{array}{l}\text { Location }(\mu) \\
\text { Scale }(ß)\end{array}$ & $\begin{array}{l}45.507 \\
24.348\end{array}$ \\
\hline & \multirow[b]{2}{*}{ Female } & \multirow[b]{2}{*}{ Gumbel } & Location $(\mu)$ & 47.506 \\
\hline & & & Scale $(ß)$ & 23.173 \\
\hline \multirow{4}{*}{ Marital status } & \multirow{2}{*}{ Unmarried } & \multirow{2}{*}{ Gamma } & Shape $(k)$ & 7.022 \\
\hline & & & Rate $(\lambda)$ & 0.180 \\
\hline & \multirow{2}{*}{ Married } & \multirow{2}{*}{ Weibull } & Shape $(\alpha)$ & 5.312 \\
\hline & & & Scale $(\lambda)$ & 67.838 \\
\hline
\end{tabular}




\section{Survival Function with Parametric Approach}

The survival function is a function that explains the probability that a person or individual will experience an event after a certain point in time.The event in this study is defined as the incident of someone dying. The survival function with a parametric approach is calculated using the probability distribution that best fits the research data distribution.

The stages of getting the survival probability values were preceded by calculating the PDF and CDF values of the data using the corresponding probability distribution parameters for each variable (Table 3). Furthermore, the survival probability value is calculated using equation $1-C D F$. The value of the survival probability for DKI Jakarta residents based on gender and marital status that has been calculated is visualized in graphical form to facilitate interpretation of the results, as shown in Figures 1 and 2.

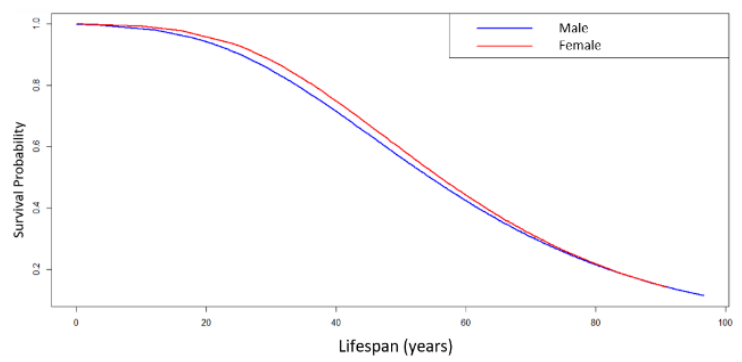

Figure 1. Survival probability comparison of DKI Jakarta residents based on gender

Figure 1 shows that the survival probability of a DKI Jakarta resident after living at the age of $t$ years will decrease as the ages increase, both for males and females. The survival probability for a male resident at birth (less than one day) is 0.99845 . This probability will decrease to 0.11523 after he has lived for 96.64 years. In line with this, the survival probability for a female at birth is valued at 0.99958 , which will decrease to 0.14229 after she has lived for 90.83 years. Based on Figure 1, it can also be seen that visually the survival probability for the female population after living for $t$ years is only slightly higher when compared to the male population of the same age.

Meanwhile, Figure 2 shows that the survival probability for the DKI Jakarta resident based on marital status variable after $t$ year will decrease as the population ages increase.

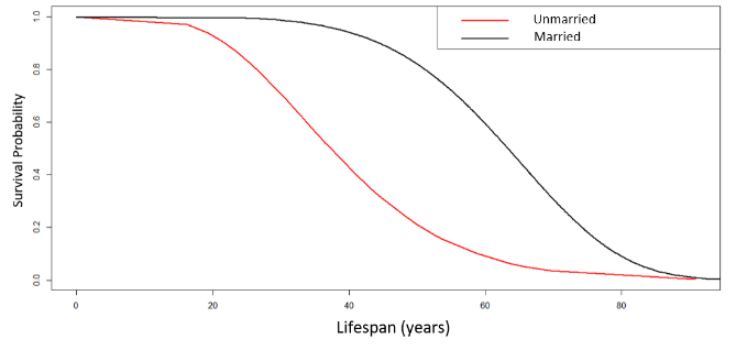

Figure 2. Survival probability comparison of DKI Jakarta residents based on marital status

The survival probability for a DKI Jakarta resident with unmarried marital status after living for 16.16 years is 0.97182 . The survival probability will decrease to 0.00334 after he or she has lived for 90.83 years. Furthermore, the survival probability for a resident with a married marital status after living for 23.67 years is 0.99628 . The survival probability will drop to 0.00143 after he or she has lived for 96.64 years. In general, Figure 2 shows that the survival probability for the married population is much greater when compared to the unmarried population. However, this needs to be proven statistically through the log-rank test.

\section{Log-rank test}

The log-rank test is a statistical method that can be used to test whether there is a difference in the survival probability for DKI Jakarta residents based on gender and marital status variables. The null hypothesis in the logrank test states that there is no difference in survival probability between categories based on gender and marital status. The null hypothesis will be rejected if the p-value of the test is smaller than the significance level set in this study, which is 0.05 . The results of the log-rank test for the two variables analyzed are shown in Table 4.

Table 4. Log-rank test statistics

\begin{tabular}{crc}
\hline Variable & $\chi^{\mathbf{2}}$ & p-value \\
\hline Gender & 0.2 & 0.627 \\
Marital status & 75.0 & $<0.001$ \\
\hline
\end{tabular}

Table 4 shows that the Chi-square value of the log-rank test based on the gender variable is 0.2 with a p-value of 0.627 . The $p$-value is much greater than 0.05 , so it can be concluded that the null hypothesis failed to be rejected. This shows no significant difference in the survival 
probability between the male and female populations.

Meanwhile, the chi-square value of the log rank test based on the marital status variable was 75.0 with p-value much smaller than 0.001 . The null hypothesis based on marital status can be rejected. This test shows a significant difference in the survival probability between unmarried people and those who are married. Furthermore, Figure 2 also shows that the survival probability values of the unmarried population is much smaller when compared to the married population. Therefore, it can be concluded that the survival probability of a resident with married status will be higher when compared to those with unmarried status.

\section{DISCUSSION}

The result of data analysis obtained through a parametric approach strengthened by testing the log-rank test provides the same conclusion that residents of DKI Jakarta, both male, and female, have the same survival probability. Meanwhile, the comparison of survival probability based on marital status variables shows different results. Married people have a greater survival probability when compared to unmarried one.

There is some research regarding the relationship between life expectancy and gender. A study by Damayanti and Wibowo (2018) regarding the risk factors for recurrent coronary heart disease in patients treated at the Surabaya Islamic Hospital from 2015 to 2016 showed gender had not significant effect on the risk of recurrent coronary heart disease survival, the highest causes of death in Indonesia and even in the world. Life expectancy is also closely related to the quality of mental and physical health, especially in the elderly. A research by Dewi (2018) in Bantul Regency (Yogyakarta) showed that the gender factor was also not significantly related to the quality of mental and physical health of the elderly population.

Several other studies have different results from the findings in this study. A research by Le, Ren, Shen, Li, and Zhang (2015) in China showed there were indications that female have a longer lifespan than male. They concluded that cancer, circulatory and respiratory diseases were the most significant contributors to the lifespan difference between males and females in their study. Male were also more susceptible to malaria, which can cause death (Zohra, Anwar, Fitri, \& Nasution, 2019). Apart from that, research by Budi et al. (2018) concluded that males were 1.8 times more likely to develop tuberculosis than females.

Contrary to the results of these three studies, research by Berdahl and McQuillan (2018) which was conducted in the United States showed that females had worse degrees of health than males. In general, health factors are closely related to the life expectancy of a person. Besides, research conducted by Rosjidi, Isro'in, and Wahyuni (2017) also showed that risk factors for cardiovascular disease like hypertension, hypercholesterolemia, obesity, lack of physical activity and diabetes mellitus are more common in females than males. The studies with different findings above indicate that research on the relationship between life expectancy and gender still needs to be studied and carried out, especially in Indonesia.

Despite the differences in the results of some of these studies, BPS DKI Jakarta Province (2019) noted the LER of the Indonesian population in 2019 for male residents was 69.44 years and for females was 73.33 years. The national LER is about one year lower than the LER of DKI Jakarta Province for male and female residents (male 70.96 years and female 74.68 years). In line with the LER of DKI Jakarta and National residents, this study shows that the survival probability and the male population's average lifespan are slightly lower than that of the female population. However, this difference was not statistically significant ( $p$-value $=$ $0.627)$. This indicates that the government programs regarding the protection of public health, in general, do not need to differentiate between male and female.

Nonetheless, efforts to improve public health, which led to an increase in LER for DKI Jakarta, need to be continuously improved. Quantity and quality of health facilities and infrastructure (General Hospital, Special Hospital, Maternity Hospital, PHC, Clinic/Health Center, Integrated service post, village maternity cottage, Pharmacy, and others) and medical personnel (specialist and general doctors, dentists, midwives, nurses, nutritionists, pharmacists, and other health workers) need to be continuously improved so that they can reach and serve all residents of DKI Jakarta down to 
the village level. In 2019, the DKI Jakarta Provincial Government had 143 General Hospitals and 47 Special Hospitals, 19 Maternity Hospitals, 1,537 clinics/health centers and 4,470 Puskesmas. Moreover, DKI Jakarta had 14,153 doctors (specialist and general), 27,149 nurses, 5,953 midwives, 4,581 pharmacists and 1,004 nutritionists (BPS DKI Jakarta Province, 2020). In addition to adequate facilities, infrastructure and medical personnel, the population with health insurance also needs to be continuously increased so that more people can access health facilities, especially those with low economies. In 2019, 50.95\% of DKI Jakarta residents had BPJS Kesehatan in the Contribution Assistance Recipient (PBI) category and $31.63 \%$ who had BPJS Kesehatan for the Non-Contribution Assistance Recipient (Non-PBI) category (BPS DKI Jakarta Province, 2020).

On the other hand, most studies in various countries report a positive relationship between health and marital status, where some of the deaths can be determined by the variable marital status (Tatangelo, McCabe, Campbell, \& Szoeke, 2017). Gellatly and Störmer (2017) offered two main explanations for why a married person had a greater LER. The first explanation is from a social perspective, where marriage can generate moral/psychological and economic support and the creation of support in terms of the division of duties and responsibilities between a person and their partner. This condition can extend the lifespan for both parties. The second reason has to do with selective explanations, where someone who has the potential to live longer will be more attractive to the opposite gender so that they are more likely to get married. They also concluded that marital status had a positive relationship with life expectancy, especially for male. A research by Herm, Anson, and Poulain (2016) also concluded that marriage could reduce the risk of death in the elderly population in Belgium. According to Gutiérrez-Vega, Esparza-Del Villar, Carrillo-Saucedo, and MontañezAlvarado (2018), marital status played an essential role in the analysis of the quality of life of the adult population on the border between the United States and Mexico. They claimed that marriage would offer a self-protective mechanism against depressive symptoms to suppress mental illness onset during late adulthood. Marriage can eliminate feelings of being alone and isolated which has great benefits for mental and physical health. In more detail, research by Mainous et al. (2011) in South Carolina (the United States) as well Yen and Lung (2013) in Taiwan showed that married people had larger telomeres than those who were unmarried. Telomeres are a component that protects human chromosomes and DNA from damage. The bigger a person's telomere, the less chance that person's cells will be damaged, thus reducing the risk of developing cancer and heart disease, which can potentially cause death.

In this study we show that residents of DKI Jakarta who are married have an average lifespan that is almost twice that of the unmarried population (62.47 years compared to 39.11 years). Besides, there is also a significant difference in the survival probability between married people and those who are unmarried ( $p$ value < 0.001).

Based on Figure 2, it is known that the survival probability of the unmarried population is significantly lower than that of the married population, especially in the age range of 20 to 80 years. In other words, the population of DKI Jakarta who died in that age range was dominated by the unmarried population. Meanwhile, at the age of under 20 years and above 80 years, the survival probabilities are not significantly different. Thus, the age of $20-80$ years is a crucial age range for the unmarried population to survive.

The results of this study indicate that the DKI Jakarta Provincial Government needs to make special efforts to increase the number of married people, for example, by implementing economic empowerment programs such as job and skills training, apprenticeships and provision of business capital. Economic factors are one of the most critical factors in influencing a person's decision to marry. This financial empowerment program can be given to workingage residents, especially those who have just completed their education at both the secondary level (senior high school and equivalent) and tertiary education (Diploma 1 to Strata 1). These economic empowerment programs can be specifically given to male residents since they are prospective heads of households who will be responsible for all the needs of their families.

The number of adolescents (10-24 years) in DKI Jakarta was significant, namely $2,261,337$ people or around $21.42 \%$ of the total population in 2019. A total of 1,129,434 
people $(49.95 \%)$ of them was male residents. Furthermore, if related to the total workforce aged 15-24 years, as many as 125,282 people or $18.28 \%$ of the population in that age range were unemployed or not working (BPS DKI Jakarta Province, 2020). The DKI Jakarta Provincial Government should focus the economic empowerment program on this jobless group so that their economic conditions will be better and increase their chances of getting married.

Marriage for young people is also related to the phenomenon of early marriage. Angraini et al. (2019) stated that there were three variables that influence early marriage, namely knowledge, age at menarche and the media. Age of menarche was the most dominant variable in the phenomenon of early marriage in their research. The DKI Jakarta Provincial Government needs to wisely handle the phenomenon of early marriage, for example, through optimizing the Planning Generation (GenRe) program. Genre is one of the government's programs specifically for adolescents to help prepare family life to achieve youthful strength to realize family resilience through small, happy, and prosperous families in the future. A study by Rini and Tjadikijanto (2018) showed that the achievement of the indicators for Adolescent Reproductive Health (ARH) and Adolescent Family Development (AFD), and the Center for Counseling Information for Adolescents/Students and Marital Age Maturation (MAM) in the GenRe program in general were still relatively low in Indonesia. The DKI Jakarta Provincial Government needs to make an integrated effort to improve the achievement of the GenRe indicators. Some of the integrated steps above are expected to significantly increase the LER of the population of DKI Jakarta so that it will also increase the HDI, which will ultimately create a quality life for all residents of DKI Jakarta in particular and all Indonesian population in general.

Research limitations are essential to mention. Limited access to the socioeconomic status of the study sample is one of the limitations of this study. Socioeconomic status plays a vital role in a person's life, especially those related to health factors. A person who has an excellent socioeconomic condition will generally have access to adequate health services and get nutritious food intake to have a good health condition. This condition is different from those who are in poor socioeconomic conditions. Besides, the cause of death of the study sample was also not reported in detail, so that further analysis of the causes of the high and low lifespan of the research samples could not be carried out. Nevertheless, the large number of samples $(n=464)$ in this study is believed to minimize the bias of the study results. Lastly, this study only uses four probability distributions. The use of other probability distributions might improve the accuracy of the survival probability calculation of the research sample.

\section{CONCLUSIONS AND SUGGESTIONS}

\section{Conclusions}

The results of data analysis that have been carried out show that the male population of DKI Jakarta has the same survival probability as the female population. Meanwhile, married residents tend to have a greater survival probability when compared to unmarried residents. This result shows that marital status can significantly increase the LER of the population.

\section{Suggestions}

The Provincial Government of DKI Jakarta is advised to increase the percentage of the married population in an effort to increase LER, which leads to an increase in regional HDI. The Provincial Government of DKI Jakarta can be organizing several economic empowerment programs such as job and skills training, apprenticeships, and providing business capital to support these efforts. These economic empowerment programs should be devoted to people in the age range of 15-24 years who are not working (unemployment), especially those who are males. The DKI Jakarta Provincial Government also needs to prepare qualified premarital youth groups to optimize the Planning Generation (GenRe) program. Besides, efforts to improve the level of public health, in general, also need attention. Health facilities and infrastructures, medical personnel and the coverage of public health insurance programs need to be continuously improved in quantity and quality. 


\section{REFERENCES}

Angraini, W., Pratiwi, B. A., Febriawati, H., Yanuarti, R., Anita, B., dan Oktarianita, O., 2019. Faktor yang Mempengaruhi Terjadinya Pernikahan Usia Dini. Jurnal Biometrika dan Kependudukan, 8(2), pp. 183-191.

Beckman, K., 2016. 9 factors that affect longevity. Think Advisor. Available at: <https://www.thinkadvisor.com/>.

Berdahl, T. A., and McQuillan, J., 2018. SelfRated Health Trajectories among Married Americans: Do Disparities Persist over 20 Years? Journal of Aging Research, 2018, pp. 1-8.

BPS Provinsi DKI Jakarta., 2019. Angka Harapan Hidup (AHH) Menurut Provinsi dan Jenis Kelamin, 2010-2018. Available at: <https://www.bps.go.id/>.

BPS Provinsi DKI Jakarta., 2020. Provinsi DKI Jakarta dalam Angka 2020. Jakarta: BPS Provinsi DKI Jakarta.

Budi, I. S., Ardillah, Y., Sari, I. P., dan Septiawati, D., 2018. Analisis Faktor Risiko Kejadian penyakit Tuberculosis Bagi Masyarakat Daerah Kumuh Kota Palembang. Jurnal Kesehatan Lingkungan Indonesia, 17(2), pp. 8794.

Chan, M. F., and Kamala Devi, M., 2015. Factors Affecting Life Expectancy: Evidence from 1980-2009 Data in Singapore, Malaysia, and Thailand. Asia-Pacific Journal of Public Health, 27(2), pp. 136-146.

Damayanti, F. P., dan Wibowo, A., 2018. Analisis Survival Penyakit Jantung Koroner Berulang. Jurnal Biometrika dan Kependudukan, 6(1), pp. 43-51.

Danasari, L. S., dan Wibowo, A., 2017. Analisis Angka Harapan Hidup di Jawa Timur Tahun 2015. Jurnal Biometrika dan Kependudukan, 6(1), pp. 17-25.

Dewi, S. K., 2018. Level Aktivitas Fisik dan Kualitas Hidup Warga Lanjut Usia. Media Kesehatan Masyarakat Indonesia, 14(3), pp. 241-250.

Dwiningtias, Y. D. P., dan Mahmudah, M., 2019. Analisis Regresi Ordinal Model Logit untuk Mengidentifikasi Faktor yang Mempengaruhi Indeks Pembangunan Manusia. Jurnal Biometrika dan Kependudukan, 8(2), pp. 174-182.

Gellatly, C., and Störmer, C., 2017. How Does
Marriage Affect Length Of Life? Analysis of a French historical Dataset from an evolutionary Perspective. Evolution and Human Behavior, 38(4), pp. 536-545.

Gutiérrez-Vega, M., Esparza-Del Villar, O. A., Carrillo-Saucedo, I. C., and MontañezAlvarado, P., 2018. The Possible Protective Effect of Marital Status in Quality of Life Among Elders in a U.S.Mexico Border City. Community Mental Health Journal, 54(4), pp. 480484.

Hanifa, S., dan Wibowo, A., 2017. Faktor yang Memengaruhi Kemiskinan di Provinsi Jawa Timur Tahun 2014. Jurnal Biometrika dan Kependudukan, 6(2), pp. 136-143.

Herm, A., Anson, J., and Poulain, M., 2016. Living Arrangements and Marital Status: A Register-Based Study of Survival of Older Adults in Belgium at the Beginning of the 21st Century. Ageing and Society, 36(10), pp. 21412162.

Jiang, R., 2015. Introduction to Quality and Reliability Engineering. Berlin, Heidelberg: Springer.

Le, Y., Ren, J., Shen, J., Li, T., and Zhang, C.F., 2015. The Changing Gender Differences in Life Expectancy in Chinese Cities 2005-2010. PloS One, 10(4), e0123320.

Mainous, A. G. I., Everett, C. J., Diaz, V. A., Baker, R., Mangino, M., Codd, V., and Samani, N. J., 2011. Leukocyte Telomere Length and Marital Status among Middle-Aged Adults. Age and Ageing, 40(1), pp. 73-78.

Rini, I. M., dan Tjadikijanto, Y. D., 2018. Gambaran Program Generasi Berencana (GenRe) di Indonesia dan di Provinsi Jawa Timur Tahun 2017. Jurnal Biometrika dan Kependudukan, 7(2), pp. 168-177.

Rosjidi, C. H., Isro'in, L., and Wahyuni, N. S. (2017). Differences in Risk Factor of Cardiovascular Disease Risk on Rural and Urban Population. KEMAS: Jurnal Kesehatan Masyarakat, 13(1), pp. 6976.

Sari, U., Harianto, H., dan Falatehan, A. F., 2016. Strategi Meningkatkan Angka Harapan Hidup (AHH) Melalui Alokasi Anggaran Kesehatan di Provinsi Jawa 
Barat. Jurnal Manajemen Pembangunan Daerah, 8(1), pp. 29-41.

Tatangelo, G., McCabe, M., Campbell, S., and Szoeke, C., 2017. Gender, Marital Status and Longevity. Maturitas, 100, pp. 64 69.

Yen, Y.-C., and Lung, F.-W., 2013. Older Adults with Higher Income or Marriage Have Longer Telomeres. Age and Ageing, 42(2), pp. 234-239.

Zohra, A. F., Anwar, S., Fitri, A., dan Nasution, M. H., 2019. Klasifikasi Wilayah Provinsi Aceh Berdasarkan Tingkat Kerentanan Kasus Malaria Tahun 2015 - 2018. Jurnal Kesehatan Lingkungan Indonesia, 18(1), pp. 25-33. 